\title{
PELATIHAN PEWARNAAN KAIN DENGAN TEKNIK JUMPUTAN UNTUK ANAK-ANAK UPTD PANTI SOSIAL PERLINDUNGAN ANAK DHARMA SAMARINDA
}

\author{
Dita Andansari dan Etwin Fibrianie \\ Jurusan Desain, Program Studi Desain Produk, Politeknik Negeri Samarinda \\ Email : ditaandansari@polnes.ac.id
}

\begin{abstract}
ABSTRAK
Anak-anak yang diasuh dalam panti asuhan adalah salah satu khalayak sasaran yang perlu untuk dibekali keterampilan guna dapat berkontribusi juga dalam industri kreatif mengingat di masa depannya mereka harus dapat menghidupi diri sendiri karena sebagian besar dari mereka sudah tidak mempunyai orang tua kandung yang dapat membimbing dan memberikan bantuan keuangan kepada mereka. Salah satu solusi yang diberikan adalah pelatihan pewarnaan kain menggunakan teknik jumputan sebagai salah satu bekal usaha. Belum pernah ada yang melakukan pelatihan pewarnaan kain dengan teknik jumputan untuk anak-anak UPTD (Unit Pelaksana Teknis Daerah) Panti Sosial Perlindungan Anak Dharma Samarinda. Pewarnaan jumputan pada kain dapat dijadikan sebagai produk fesyen dan menurut penelitian bahwa Pengembangan Industri Fesyen Sebagai Industri Kreatif Unggulan Untuk Mendorong Pembangunan Ekonomi Indonesia, menyimpulkan bahwa Industri fesyen adalah potensial dan menjadi unggulan bagi penyumbang PDB Indonesia dan sebagai penyedia lapangan kerja yang potensial sebagai solusi mengatasi jumlah pengangguran di Indonesia.(Riana,2012). Tahapan dalam pembuatan kain dengan pewarnaan teknik jumputan adalah sebagai berikut : Pelipatan kain, Pengikatan kain, Pencelupan zat pewarna, Pembukaan ikatan kain, Penjemuran,Kain jadi. Peserta yang mengikuti pelatihan sejumlah lima belas orang dengan umur sekitar 6 sampai dengan 17 tahun baik yang terdiri dari laki-laki dan perempuan. Peserta mengikuti pelatihan dengan semangat dan sudah menunjukkan bisa menghasilkan kain dengan teknik pewarnaan jumputan. Kegiatan pelatihan ini sudah dimasukkan beritanya ke surat kabar Samarinda Pos terbit pada Hari Selasa, 10 November 2020.
\end{abstract}

Kata Kunci: Kain Jumputan, UPTD Panti Sosial Perlindungan Anak Dharma, Samarinda

\section{PENDAHULUAN}

Unit Pelaksana Teknis Daerah (UPTD) Panti Sosial Perlindungan Anak Dharma merupakan sebuah panti yang telah mengalami perubahan dan perkembangan. Pada tahun 1940-an, tokoh masyarakat bernama H.Yusuf di sekitar jalan Wajo Kampung Baqa
Samarinda seberang memprakarsai kegiatan keagamaan.

Selanjutnya di sekitar tahun 1979, nama tugas dan fungsi mengalami perubahan beberapa kali. Sasana Karya Dharma adalah nama awal dari (UPTD) Panti Sosial Perlindungan Anak Dharma dengan kegiatan berupa memberikan 
pelayanan bagi seluruh penyandang masalah kesejahteraan sosial. Kemudian berubah menjadi Panti Sosial Karya Dharma. Pada saat itu masalah yang dilayani dibawah Kantor Wilayah Departemen Sosial Kalimantan Timur, masih beragam meliputi lanjut usia, tuna wisma,anak terlantar dan lain-lain. Kemudian berubah menjadi Panti Sosial Asuhan Anak Dharma dimana pelayanan dilakukan secara khusus kepada anak yatim piatu. Moto pelayanan to help people to help them selves pada saat itu dan diberlakukan praktek profesi pekerjaan sosial sebagai dasar proses pelayanan dan penyantunan dengan.

Pada periode tahun 1999, adanya likuidasi dari pemerintah pusat menyebabkan status induk organisasi panti berubah-ubah.pada masa transisi inilah Panti Sosial Asuhan Anak Dharma menjadi bagian unit pelaksana tugas Pemerintah kota Samarinda. Namun dengan adanya semangat otonomi daerah dengan mengacu pada surat Gubernur Kalimantan timur No 16 September tahun 2001 Panti Sosial Asuhan Anak Dharma menjadi unit pelaksana dengan tugas dan fungsi yang lebih beragam.
Unit Pelaksana Teknis Daerah Dinas Sosial Provinsi Kalimantan Timur sejak tanggal 29 september 2002 menempati sarana dan prasarana baru berlokasi di Jln H.A.M.M.Riffaddin Samarinda seberang. Unit Pelaksana Teknis Daerah Dinas Sosial Provinsi Kalimantan Timur dapat menampung 100 orang klien berupa anak terlantar dari seluruh wilayah Provinsi Kalimantan Timur meliputi 13 wilayah Kabupaten/Kota dan difasilitasi dengan sarana menggunakan sistem cottage/wisma, berjumlah 10 wisma.

Unit Pelaksana Teknis Daerah (UPTD) Panti Sosial Perlindungan Anak Dharma mendapat kewenangan sebagai pendamping kerohanian, Pendidikan dan Publikasi setelah adanya SK Gubernur tahun 2007 nomor 350/K.89/2007 tentang pembentukan koalsi Anti Perdagangan Orang ( Traficking ) dan Kekerasan dalam rumah tangga ( KDRT) Kalimantan Timur dimana tertera dalam SK tersebut, maka dilakukan pengembangan model pelayanan bersifat Perlindungan Khusus selain pada pola pengasuhan yang ada.

Dengan adanya tuntutan PP no 41 tahun 2007, maka dilakukan Pengembangan model pelayanan ini. 
Salah satu prinsip etika praktek Pekerjaan Sosial dimana pekerja sosial dalam memberikan pelayanan haruslah berdasarkan pada karakteristik kebutuhan anak oleh karena itu model pelayanan panti bersifat pada perlindungan khusus dengan berdasarkan pada pengetahuan dan ketrampilan praktek profesi pekerjaan sosial.

Karena usia anak-anak dalam Unit Pelaksana Teknis Daerah (UPTD) Panti Sosial Perlindungan Anak Dharma berusia produktif maka perlunya diberikan keterampilan khusus yang dapat dijadikan bekal untuk masa depan sebagai salah satu alternatif mendapatkan penghasilan.

Sebagai salah satu usaha untuk memberikan keterampilan kepada anakanak Unit Pelaksana Teknis Daerah (UPTD) Panti Sosial Perlindungan Anak Dharma Samarinda, belum pernah ada yang melakukan pelatihan pewarnaan kain dengan teknik jumputan. Pewarnaan jumputan pada kain dapat dijadikan sebagai produk fesyen dan menurut penelitian bahwa Pengembangan Industri Fesyen Sebagai Industri Kreatif Unggulan untuk Mendorong Pembangunan Ekonomi Indonesia, menyimpulkan bahwa
Industri fesyen menjadi industri potensial dan unggulan bagi penyumbang PDB Indonesia dan sebagai penyedia lapangan kerja yang potensial sebagai solusi mengatasi jumlah pengangguran di Indonesia (Riana,2012).

Pewarnaan kain dengan teknik jumputan sangatlah mudah dan tidak memerlukan biaya yang mahal, sehingga sangat sesuai diajarkan pada anak-anak panti asuhan,dalam kegitana ini anak-anak Unit Pelaksana Teknis Daerah (UPTD) Panti Sosial Perlindungan Anak Dharma Samarinda. Menurut Ristiani dan Sulistyaningsih (2016) menyimpulkan bahwa dari penelitian telah berhasil diciptakan enam belas teknik lipat dan enam belas motif tritik jumputan. Hasil pengujian menunjukkan memenuhi standar sebagai bahan sandang, Adapun pengujian dilakukan terhadap ketahanan luntur warna terhadap pencucian, keringat, cahaya, gosokan dan penekanan panas pada kain warna sintetis maupun alam.

Salah satu upaya alih teknologi kepada masyarakat bisa dilakukan dalam kegiatan pengabdian kepada Masyarakat. Kegiatan pengabdian kepada masyarakat dengan tema 
pelatihan desain yang sudah dilakukan oleh pihak lain seperti pemberdayaan pengrajin melalui inovasi "Remitan" (Purwaningrum, dkk 2020), pelatihan desain kreatif marketplace dan media sosial (Ayuni, dkk. 2020) dan pengembangan kreativitas anak asuh berbasisi TI (Karyadiputra, dkk. 2019) terbukti mampu menambah keterampilan dari para peserta pelatihan. Unit Pelaksana Teknis Daerah (UPTD) Panti Sosial Perlindungan Anak Dharma membuat desain kain dengan teknik jumputan. Luaran dari kegiatan ini adalah kain dengan pewarnaan jumputan dan dimuat di surat kabar.

\section{METODE PELAKSANAAN}

Pewarnaan kain dengan teknik jumputan adalah salah satu alternative keterampilan yang bisa digunakan untuk usaha dan menghasilkan uang. Sebelumnya anak-anak Unit Pelaksana Teknis Daerah (UPTD) Panti Sosial Perlindungan Anak Dharma belum pernah dilatih teknik jumputan, sehingga membutuhkan pendekatanpendekatan yang sederhana, efisien dan mudah diterima oleh masyarakat secara umum. Tahapan yang akan dilakukan adalah :
1. Ceramah dan Penyuluhan

Metode ceramah digunakan untuk memberikan pengetahuan dasar proses pembuatan kain jumputan.

2. Workshop/Pelatihan

Workshop dilakukan dengan cara praktik langsung pembuatan kain dengan pewarnaan teknik jumputan

Tahapan dalam pembuatan kain dengan pewarnaan teknik jumputan adalah sebagai berikut :

a. Pelipatan kain

b. Pengikatan kain

c. Pencelupan zat pewarna

d. Pembukaan ikatan kain

e. Penjemuran

f. Kain jadi

\section{HASIL DAN PEMBAHASAN}

Pelatihan pewarnaan kain dengan teknik jumputan diikuti oleh lima belas (15) anak-anak panti asuhan Unit Pelaksana Teknis Daerah (UPTD) Panti Sosial Perlindungan Anak Dharma Samarinda dengan umur sekitar 6 sampai dengan 17 tahun baik yang terdiri dari laki-laki dan perempuan. Di awal dijelaskan pengetahuan dasar proses pembuatan kain jumputan. Penjelasan yang disampaikan diantaranya adalah pengertian dari teknik jumputan, jenis kain yang bisa 
digunakan, jenis pewarna yang bisa dipakai, teknik memunculkan bentukbentuk yang bisa dihasilkan setelah diwarna serta langkah-langkah dalam pewarnaan kain dengan teknik jumputan.

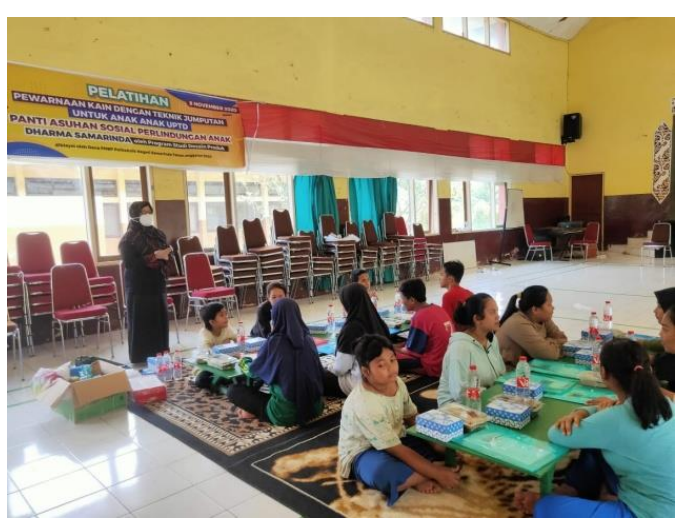

Adapun bahan, alat dan langkah dalam pewarnaan jumputan bisa dijelaskan seperti berikut :

Bahan yang diperlukan untuk praktek pelatihan pewarnaan kain dengan teknik jumputan adalah Pewarna Remasol/wantex 25-50 gram, Garam dapur 2 sendok, Air 1-2 liter. Karet gelang, Tali raffia dan Kelereng.

Sedangkan perlatan yang diperlukan adalah Panci, Kompor, Ember, Gunting, Pensil, Penghapus dan Plastik $1 \mathrm{~kg}$.

Adapun cara dan tahapan dalam pembuatan pewarnaan kain dengan teknik jumputan adalah pertama-tama membuat Pola di kain, setelah itu proses Pengikatan kain, tahapan selanjutnya adalah Perebusan pewarna dan proses terakhir adalah Memberikan warna pada kain yang sudah diikat.

Setelah diberikan penjelasan tentang pengetahuan pewarnaan kain dengan teknik jumputan, maka dilaksanakan praktek langsung pewarnaan kain dengan teknik jumputan dengan dijelaskan dan dicontohkan terlebih dahulu oleh pelaksanan pelatihan. Berikut adalah tahapan pelaksanaan praktek pewarnaan kain dengan teknik jumputan di Unit Pelaksana Teknis Daerah (UPTD) Panti Sosial Perlindungan Anak Dharma Samarinda yang dilaksanakan pada Hari Minggu, tanggl 8 November 2020.

1. Proses sketsa konsep bentuk yang diinginkan di kain

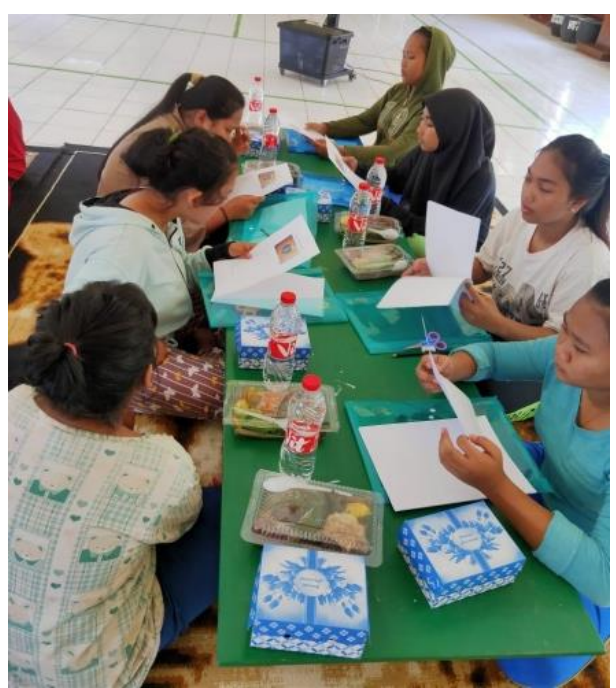


2. Proses pembuatan pola atau bentuk dengan teknik diikat baik diberi material pembentuk seperti kelerang, plastik maupun hanya dengan karet saja.

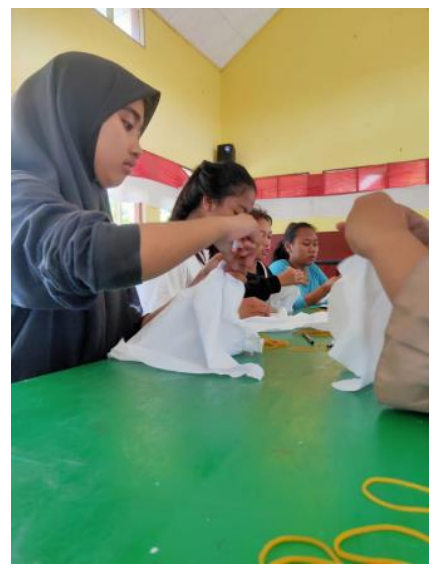

3. Pembuatan larutan warna

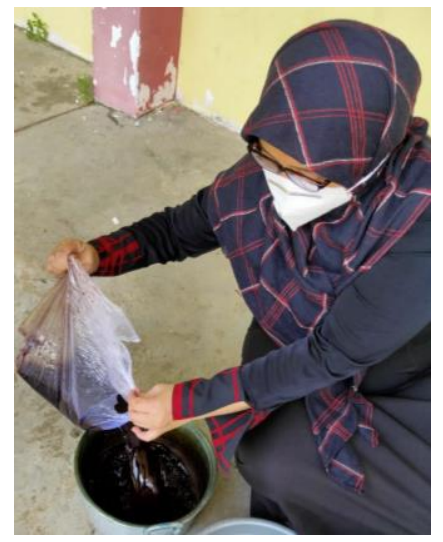

4. Pencelupan kain pada larutan warna yang sudah dibuat

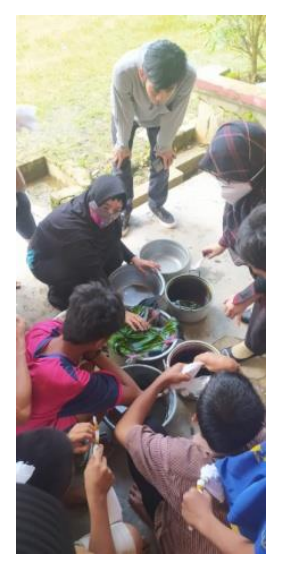

5. Penjemuran

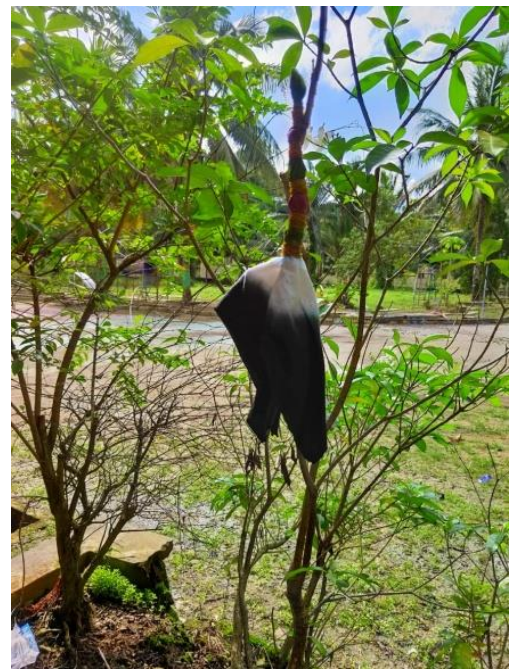

6. Produk akhir

Peserta berhasil membuat pola lingkaran berwana dengan teknik jumputan.
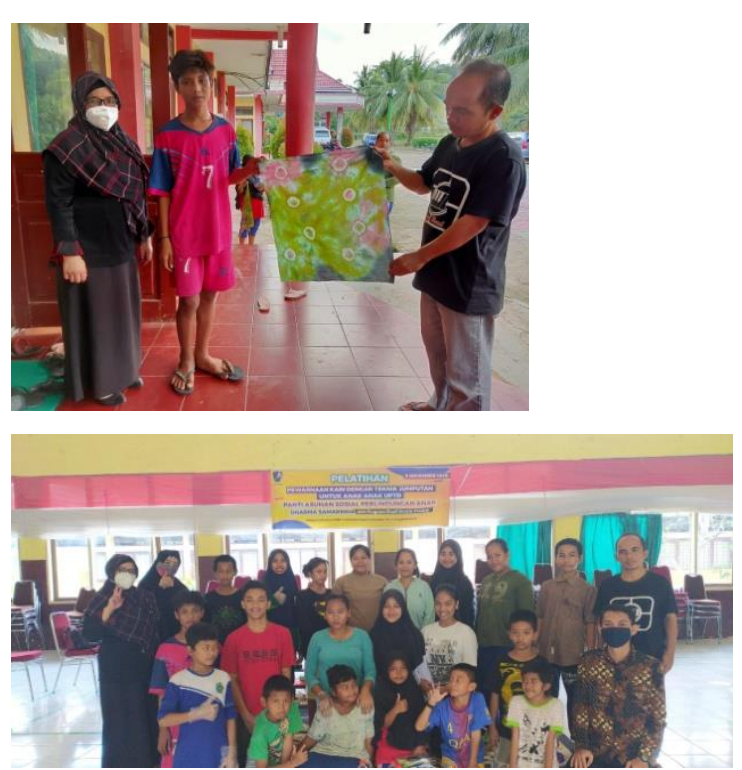

\section{KESIMPULAN}

Setelah dilaksanakan praktek pembuatan kain dengan teknik pewarnaan jumputan, peserta merasa senang dan mendapatkan keterampilan baru yang bisa dijadikan bekal ke 
depannya. Di akhir kegiatan pelatihan, peserta diberikan peralatan serta bahan yang bisa digunakan selanjutnya untuk praktek mandiri. Pemberian keterampilan serupa sangat diperlukan anak-anak Unit Pelaksana Teknis Daerah (UPTD) Panti Sosial Perlindungan Anak Dharma Samarinda untuk bekal yang dapat digunakan sebagai alternative untuk meningkatkan taraf hidup para seperta.

\section{DAFTAR PUSTAKA}

Ayuni \& Kurniawan. Pelatihan Desain Kreatif Marketplace dan Media Sosial Bagi Pengrajin Batu Permata Khas Banjar Martadiputra dalam Menarik Minat Pembeli. Al Ikhlas Jurnal Pengabdian. Vol. 5 No. 2 (2020).

Karyadiputra, dkk. Pengembangan Kreativitas Anak Asuh Berbasis TI dalam Menanamkan Nilai Wirausaha pada Asrama Putera
Panti Asuhan Yatim Piatu dan Dhu'afa Yayasan Al - Ashr Banjarmasin. Al Ikhlas Jurnal Pengabdian. Vol. 4 No.2 (2019)

Muslikhah, Riana I. Pengembangan Industri Fesyen Sebagai Industri Kreatif Unggulan Untuk Mendorong Pembangunan Ekonomi Indonesia. Fakultas Keguruan dan Ilmu Pendidikan Universitas Sebelas Maret Surakarta. Surakarta.

Purwaningrum, dkk. Pemberdayaan Pengrajin Melalui Inovasi Produk "Remitan" Ramah Anak Berdaya Saing Global di Kampoeng Remitan Desa Mayong Lor, Kabupaten Jepara, Jawa Tengah. Al-Ikhlas Jurnal Pengabdian. Vol.6 No. 2 (2020).

Ristiani,S. dan Sulistyaningsih,T., Pengembangan Teknik Tritik Jumputan dengan Sistem Lipat Ikat dan Lipat Jelujur. Dinamika Kerajinan dan Batik, Vol.33,No.1, Juni 2016,9-24

http://www.pemerintahkotasamarinda.c o.id

http://www.kemenperin.go.id 